\title{
Briefing: Cities of clubs
}

Chris Webster MSc, PhD, DSc(Econ), FRSA, AcSS, NTF

Professor, Cardiff University, Cardiff, UK

The 2005 American Housing Survey reveals that 11\% of residents on the west coast of the USA live in gated communities. The trend is not confined to America: just about all new housing built in China over the last 10 years is gated, with neighbourhood walls, guards, owner-governance structures, fees and neighbourhood management and investment plans based not on the municipal government model but on the model of the member-controlled club: hence the idea of 'cities of clubs'. Residential club economics are compelling. There is, in principle, no reason why large parts of British cities should not evolve in this way. While this will happen piecemeal under current laws, urban land reform that allows neighbourhoods to opt-out of municipal ownership and governance of non-strategic local public goods, could fundamentally reshape British cities for the better. It would also spawn a multi-billion pound private neighbourhood management market and replace the long-waves of urban decay and renewal that are characteristic of public ownership, with a far more responsive re-investment regime.

\section{Introduction}

There is, in most cities in most countries, an important institutional gap in public governance structure at the neighbourhood level. The urban neighbourhood is the spatial scale of consumption sharing that is most important to the average citizen but it is the least well organised for collective action (Webster, 2003). The Westminster government's current neighbourhood planning experiment partially addresses this problem but the problem is much deeper than an absence of development coordination instruments at a local scale. It is a problem with the way markets for public goods are structured. For this reason, privately governed neighbourhoods (referred to as 'club communities' after Nobel economist James Buchanan's theory of 'club goods' (Buchanan, 1965)) are emerging rapidly in cities throughout the world, threatening radically to change the way in which we order urban affairs (Le Goix and Webster, 2008; Plaut, 2011).

In a paper that asked why gated communities (a highly visible form of club community) are flourishing in some European countries but not others, Zoltan Cséfalvay (Business Minister in the Hungarian government) and the present author, found evidence that this new institution is best explained by the level of centralisation of a country's public expenditure (Cséfalvay and Webster, 2010). Tested against alternative hypotheses, this explanation had greatest statistical discriminating power - above a country's crime levels, income inequality and preference for public over private sector. It was concluded that club communities tend to emerge because of the lack of what economists call 'fiscal equivalence': an equivalence between the value of taxes paid and benefits received. In a privately supplied, owned and governed neighbourhood, fiscal equivalence is high. You get what you pay for.

Because of a misaligned incentive structure for investment, the public parts of cities do not renew themselves as they could do if organised differently. Urban renewal becomes a political process and is either undersupplied or not supplied at all. So cities pass through cycles of decline and renewal, the wavelengths of which are far too long because the political signals that trigger action only kick-in when the problems become deep enough to generate expressions of public disquiet. This would be different in a 'city of clubs'.

\section{How a city of clubs could work}

As a thought experiment, imagine a city made up of spatially contiguous territorial clubs. Instead of a network of publicly owned land used for streets, open space and facilities, edged and filled by private land parcels, imagine a patchwork of collectively owned territories transversed by the city's road grid located on public easements or on land retained under public ownership. Within these contractual communities, neighbours coordinate their affairs through micro-governance structures including those that give them the right to charge service fees and raise new assessments for investment projects. They have a constitution, voting and decision-making rules and active maintenance and investment plans. Driving through a city will take you through and past many of these neighbourhoods. Some will be physically enclosed with gates, others open (about $60 \%$ of club communities in the USA have chosen not to erect gates). Those that you pass through may charge for passage by way of telemetric charging, possibly with price determined by residents (a decentralised version of congestion charge). Onstreet parking charges might also be set and regularly adjusted by neighbourhoods, giving residents and commercial operators the ability to balance parking congestion with car-born customer footfall and parking income (Shoup, 2004). Whether or not a neighbourhood is physically enclosed with gates, all are legally enclosed and constituted as contractual communities. 
The legal enclosure of neighbourhoods into residential, commercial and mixed use club communities extends the genre established by shopping malls. Malls are highly efficient private versions of traditional High Streets. Externalities are internalised such that investments that attract more customers can be recouped from rents. In residential club communities, investments are recouped through increased house prices and rents. Owner-occupiers have a double incentive to pay the fees and assessments that support club governance: immediate use value and future resale value. Landlords have an incentive to improve not only their private properties but their shared streets and spaces to increase and/or stabilise long-term rents. The analogy with the shopping mall is more exact for rental than for owner-occupied properties, so think residential malls, co-owned by a partnership of multiple landlords.

The menu of legal institutions variously used to create contractual neighbourhoods in countries around the globe include: trusts, mutual associations, commonhold tenure, condominiums, strata title, home owners associations, residential associations, joint stock companies, private companies and other variants. The UK has community land trusts, community mutuals, commonhold associations, companies limited by guarantee and other options. None of them are perfect instruments for the job but they will continue to evolve as demand for club communities continues to rise.

\section{Effects on economy, environment and society}

In the typical British city centre, apartment lessees can currently expect to pay a service fee of perhaps $£ 2000$ per year. Less centrally, this may go down to $£ 1000$. If this is thought of as a private governance fee (a contractual version of council tax) that covers maintenance of and reinvestment in shared spaces as well as services such as security, lifts, clubhouses, swimming pools, gyms and landscaping, the figure can be thought of as the revealed demand for additional microurban government with high fiscal equivalence. If the infrastructure for private neighbourhood governance was in place throughout the city, the effect on the urban environment and level of services could be huge. There were 62 million residents in the UK in 2010 living in 25 million households. If each household had a demand of $£ 1000 /$ year for additional neighbourhood services, a 25 billion pound a year industry in continual neighbourhood improvement would be spawned. If some of the services currently provided by local authorities were transferred to private neighbourhood governments and with them a fraction of local taxes, the industry could be approaching the size of the higher education market in the UK.

This is not urban planning science fiction: approaching $100 \%$ of houses built in China's sprawling new metropolises are governed by local neighbourhood organisations. Residents pay by contractual fee for much of what we expect from our local governments. This is particularly significant in the context of a country with no recent history in modern town halls. When the functions of municipal governance had to be rediscovered after Chinese urban land reforms in the 1990s, the development industry (in its widest definition, including private developers, local governments, land owners, financiers, property management companies, commercial and residential owners and renters) apparently discovered that the most efficient way of drawing proprietary boundaries was at the edge of the neighbourhood, not just at the edge of the individual property. Multiple levels of 'front door' appeared in the urban fabric: the 'home' (apartment, town house, villa, office, shop); the apartment block or commercial building; the micro-neighbourhood (groups of a few buildings); and the larger neighbourhood (estate). More significant than the gates (many of which remain open, leaving the territories permeable for pedestrians), are the public goods that can be supplied to the spatially specific markets thus created. From the Chinese communities which the current author has visited, as from others across the world, there are many stories demonstrating the compelling logic of the residential club economy: an underused lawn ripped up a year after being constructed to build a basketball court; reusing redundant space to build a children's and grandchild's hotel in an elderly people's gated community; gates going up for more security; unused gates coming down; landscaping improved; community energy generation installed; rare flora and fauna preserved; cycle paths constructed; and so on.

As the private neighbourhood market matures, so choice increases. As imperfectly envisioned by American economist Charles Tiebout in the 1950s, a market in urban public goods and services can evolve if people vote with their feet, selecting between alternative packages of shared goods and services supplied in different jurisdictions at different prices (Tiebout, 1956). Tiebout had in mind competing cities offering different bundles of civic goods at different tax prices. The rapidly emerging intra-city market in neighbourhoods is a better practical outworking of the Tieboutian model. It describes very well what seems to be happening in countries without strongly decentralised local tax and spend jurisdictions. As a normative model it also has its attractions. A private neighbourhood market raises the total amount spent on the environment and welfare-enhancing services; it increases choice; it produces diversity and surprise in the style, design and functions of different parts of the city; it fosters responsibility; and it stimulates neighbourhood interaction and organisation. It may even encourage an old-fashioned sense of neighbourliness. In one neighbourhood visited by the current author in Pretoria, residents proudly welcomed through their (retro-fitted) gates weekend visitors from less organised neighbourhoods, attracted by the community's well-preserved and secure green walkways and parks. 
It is easy to find negative commentaries about gated communities; mostly coming from academics with an ideological agenda against what they see as the destruction of the public realm. There are undoubtedly genuine concerns raised by the vision of a city of clubs. Many worries are unsubstantiated, however, and it has been noticeable how many negative views have softened over a decade of studying this phenomenon. The real issue may not be the alleged social costs of residential clubs (increase in the fear of others, social fragmentation and so on) but the private costs. Private urban governance has a dynamic that is not at all dissimilar to cityscale politics and bureaucracy. In addition, some of the administrative costs of urban bureaucracies are replaced by legal costs. The costs of managing urban affairs by contract (Webster, 2005) may in the end prove too costly, as the levels of litigation associated with gated communities in the USA may suggest (McKenzie, 2003). Quality of voluntary (nonprofessional) neighbourhood governors and principal-agent problems arising from property management companies (agent) and home-owner association (principal) relationships are other risks. This is all part of the social experiment underway, however. The current author's guess would be that the economics of private neighbourhoods is compelling enough for the genre to take over large parts of our cities. The present author believes that club communities are here to stay, at least for a while (these things always cycle in longer term social experiments). General-purpose municipal governments owning and servicing interstitial space between private buildings may prove to be a peculiarly twentieth century phenomenon associated with the era of modernism and municipal socialism.

\section{Urban land reform and the Big Society}

Some have referred to the gating of neighbourhoods as the medievalisation of the city. There is something in the notion but it misses the point that private urban governance is an emergent spontaneous phenomenon driven by the city's ability, as a complex adaptive system, to self-organise in pursuit of greater wealth and welfare. In the UK, this process is inhibited by the local state's monopoly control over neighbourhood public goods. For the residents of Britain's drab suburban housing estates emaciated by years of underinvestment to enjoy the same quality of local environment, facilities and services as families with equivalent real incomes and status in China, Malaysia (where this briefing paper was written) and many other places less wedded to the twentieth-century municipal governance model, there needs to be urban land reform. Something equivalent to school opt-out is needed, where neighbourhoods, variously defined and constituted can take control of their local spaces, with various rights transferred from the local state to a legally constituted residents' association, mutual association, trust or shareholding company. There would need to be a menu of legal vehicles to transfer property rights to suit particular local circumstances. The right of the state would be a residual one: it would retain control over $(a)$ those functions and responsibilities that residents do not want and $(b)$ trunk infrastructure necessary for the functioning of the city as a whole. Rights and responsibilities would be realigned contractually in a way that maximises the value of the neighbourhood to principal stakeholders (Webster, 2003).

In a recent study of Seoul, Korea, conducted with co-author Yoonseuk Woo, it was found that a mature private neighbourhood market will efficiently price local public goods if allowed to grow without undue regulatory hindrance (Woo and Webster, 2011). In fact, the regulation has the opposite affect in South Korea, as in many other countries: it is designed to encourage more not less privately supplied neighbourhood facilities. Seoul's high rise gated apartment complexes are required by law to deliver a certain quantity of public goods such as (depending on their size) kindergartens, primary schools, parks, parking and security; and to create sufficient sink funds to be able to maintain and reinvest in these club facilities. This is evidence that private and public urban governance institutions will co-evolve where they are allowed to; in this case, public laws being used to structure the private neighbourhood market to secure the interests of residents.

A particularly large private suburb in the city of Wuhan in central China that the author came across during a UN assignment has been built, governed and managed by a profit company (chaired by an entrepreneur named Mao). It provides private social security to its residents, free annual medical check-ups for the over sixties and children and scholarships for its young people going to university - all subsidised from the company's operating profits. Its landscaped gardens, sports facilities and courteous private security force of 60 officers are all immaculate. In the private town hall, pictures of happy residents waving ribbons in synchronised outdoor dance formation are reminiscent of Mao's propaganda posters of a bygone age; and when the author asked about the obviously high level of community spirit flowing through the veins of the private city, he learned that Entrepreneur Mao saw his creation as a modern means of achieving communist ideals: a contractual community themed on a romantic memory of communism circa 1950 . It demonstrably worked very much better than the original dream.

Prime Minister Cameron's Big Society quietly slipped off the agenda because no one could really understand what it meant or could imagine how to achieve it. Liberating urban land from state control and turning the property market into a neighbourhood market might be the big idea waiting to happen in Britain's dysfunctional cities. 


\section{REFERENCES}

Buchanan J (1965) An economic theory of clubs. Economica 32(125): $1-14$.

Cséfalvay Z and Webster C (2010) Gates or no gates? A crossEuropean enquiry into the driving forces behind gated communities. Regional Studies DOI:10.1080/ 00343404.2010 .505917$.

Le Goix R and Webster C (2008) Gated communities. Geography Compass 2(4): 1189-1214.

McKenzie E (2003) Common interest housing in the communities of tomorrow. Housing Policy Debate 14(1/2): 203-234.

Plaut PO (2011) The characteristics and tradeoffs of households choosing to live in gated communities. environment and Planning B. Planning and Design 38(5): 757-775.

Shoup D (2004) The High Cost of Free Parking. American Planners Association, Planners Press, Washington DC, USA.

Tiebout C (1956) A pure theory of local government expenditure. Journal of Political Economy 64(x): 416-424.

Webster CJ (2003) The nature of the neighbourhood. Urban Studies 40(13): 2591-2612.

Webster CJ (2005) Editorial: Diversifying the institutions of local planning. Economic Affairs 25(4): 4-10.

Woo Y and Webster C (2011) International Journal of Urban and Regional Research, in press.

\section{WHAT DO YOU THINK?}

To discuss this briefing, please email up to 500 words to the editor at journals@ice.org.uk. Your contribution will be forwarded to the author(s) for a reply and, if considered appropriate by the editorial panel, will be published as discussion in a future issue of the journal.

Proceedings journals rely entirely on contributions sent in by civil engineering professionals, academics and students. Papers should be 2000-5000 words long (briefing papers should be 1000-2000 words long), with adequate illustrations and references. You can submit your paper online via www.icevirtuallibrary.com/content/journals, where you will also find detailed author guidelines. 